\title{
Impact of Soil Amendments and Irrigation Water on Growth and Flowering of Rosa Plant Grown in Sandy Soil Rosa hybrida
}

\author{
Sohier G. El-Alsayed ${ }^{1}$, Sahar M.Ismail ${ }^{2}$
}

\begin{abstract}
Pot experiments were conducted for two successive seasons in Antoniadis Garden, Ornamental Plant Research, Horticulture research Institute. Alexandria, Egypt. Rose plants were grown in sandy soil incorporated with organic compost of municipal solid waste (CMSW)at two levels (5 and $15 \% \mathrm{w} / \mathrm{w})$ and polyacrylamide at two levels $(0.1$ and $0.2 \% \mathrm{w} / \mathrm{w})$ under irrigation regime at two rates $(250 \mathrm{ml} / \mathrm{plant}$ and $500 \mathrm{ml} / \mathrm{plant} / 3$ times per week) to study their effect on the growth, flowering, water consumption, chemical contents of rose plants and improvement of hydro-physic-chemical properties of sandy soil under the study. The obtained results showed that the irrigation water rates did not significantly affect the vegetative parameters, the flowering characteristics except for the flowering time that was significantly reduced. The early flowering was recorded at the lower irrigation rate in the $2^{\text {nd }}$ season. The $K$, chlorophyll and carbohydrates contents significantly increased in one season only. Anthocyanin content did not significantly increase. Pre-planting addition of CMSW at the higher level $(15 \%$ w/w $)$ significantly stimulated the vegetative parameters in the two seasons. The organic compost at level of $15 \% \mathrm{w} / \mathrm{w}$ of CMSW was more effective in promoting the early flowering (45.9 day) and the heavier flower dry weight (3.26g), prolonged vase life were 7.79 and 7.50 day, maximum number of flowers/plant were 7.82 and 5.08 in the two seasons, respectively. The tallest peduncle was 32.34 and $32.07 \mathrm{~cm}$ and the longest duration period was 5.72 and 6.19 in the two seasons, respectively. The $N, P$ and $K$ chemical contents, the total chlorophyll, carbohydrates and anthocyanin were significantly stimulated at the higher level $(15 \% \mathrm{w} / \mathrm{w})$ of CMSW compared to the lower level $(5 \% \mathrm{w} / \mathrm{w})$. Amendment of sandy soil with the hydrophilic synthetic polyacrylamide (PAM) at the level $(0.2 \% \mathrm{w} / \mathrm{w})$ significantly reduced the flowering time, while number of flowers/ plant and flower diameter as well as flower dry weight. The total chlorophyll and carbohydrates contents were significantly accumulated in the leaves as a result of utilizing PAM at level $(0.2 \% \mathrm{w} / \mathrm{w})$. Saturated hydraulic conductivity $\left(K_{\text {sat }}\right)$ increase with increasing PAM concentrations. The study recommended to grow rose plants in sandy soil under amended with preplanting organic compost (CMSW) at level $(15 \% \mathrm{w} / \mathrm{w})$ and PAM at level $(0.2 \% \mathrm{w} / \mathrm{w})$ with irrigation rate at $250 \mathrm{ml} /$ plant/ 3times per week.
\end{abstract}

Keywords: polyacrylamide, organic compost, Rose plant, sandy soil.

${ }^{1}$ Agriculture Research Center, Horticulture Research Institute, Antoniadis Research Branch, Alexandria, Egypt.

${ }^{2}$ Desert Research Center, Department of Soil Water Resources and Desert Soils, Soil Physics and Chemistry Division, Cairo, Egypt. Received September 11, 2017, Accepted September 30, 2017

\section{INTRODUCTION}

Rosa hybrida of the Rosaceae family is one of the most important ornamental shrubs in Egypt and all over the world. It is cultivated for local uses as attractive cut flower in different aspects of the arrangements, in gardens landscape as well as in the manufacture. It plays a vital part in the national economy of Egypt for its great value in exportation. Newly reclaimed soils are potentials for horizontal expansion and increasing the agriculture production in Egypt, especially the widespread desert lands in the northern coast to supply the plants with their requirements from nutrients, water and air along the growth season (Askar, 1988). Soil conditioners either the natural organic or the hydrophilic polymers are widely utilized to compensate the limited supply of the nutrients as well as increase water use efficiency on Dendrathema grandiflorum by (John and David,2000; Abd El-Hady and El Dardiry, 2012; Hassan and Mahmoud, 2013 and Regiane et al., 2005). Applying water absorbing materials to soils may be a viable alternative and practical strategy for solving the problems of limited and intermittent irrigation water. These soil amendments can improve soil physical and chemical properties and soil nutrient status and have a positive impact on soil microorganisms (Mann et al., 2011). Synthetic chemical polymers that absorb water by about 400 times or more than their own weight; have been investigated as soil amendments to improve soil water holding capacity (Huettermann et al., 2009). Thus, plant growth could be improved with limited water supply in sandy soils (Islam et al., 2011) that increased water and fertilizer use efficiency for plants. From the physical point of view, the polymers influenced infiltration rates, density, soil structure, compaction, aggregate stability, crust hardness, and evaporation rates (Sepaskhah and Basrafshan-Jahromi, 2006). They are considered safe and non-toxic and will completely decompose to carbon dioxide, water, and ammonia and potassium ions (Trenkel, 1997). Their impact extends up to five years after application (Holliman et al., 2005) and thereby increases farmers' economic return. Adding the organic compost into sandy soils proved highly beneficial effect on both soil 
characters and plant growth. Decomposition of the compost allows more releasing of inorganic elements in available form to be more easily taken up by the plant roots. In addition, organic acids released during the decomposition help in more releasing of the nutrients from the mineral portion of the soil by reducing soil $\mathrm{pH}$ (Shanks and Gouin, 1985). Organic matter absorbs water like sponge, increases soil moisture for a long time, thus water use efficiency (WUE) could be improved (John and David, 2000). Progressive improvement of the growth, flowering and chemical content of several ornamental plants was lined out as result of amending the sandy soil with the organic soil conditioners (Shanks and Gouin, 1985; Smith, 1993; Cox, 1995 on Tagetes erecta; Abass and Askar, 1999; Klock, 2000; Abass, 2003 and Abd-Ella, 2011). Meanwhile, Khattabet al., 2002 on Salvia splendense and El- Naggar et al., 2004 on Cyperus Papyrus, Elshanhorey et al., 2010 on tuberose plants and Jouyban and Moosaui, 2014 proved that vegetative growth, flowering, the chemical and nutrients elemental composition were enhanced beside the significant improvement of water use efficiency in sandy soil amended with organic matter and subjected to irrigation regime. Hydrophilic polyacrylamide gel (PAM) is successfully proved highly beneficial effect on improving physic-chemical properties of the soil under reclamation (Askar, 1991; and Bouranis et al., 1995). Lentez et al., 2001; Kay-shoemake et al., 2000; Shakoor et al., 2012 and Ayman et al., 2015 on pomegranate trees reported that PAM enhances water holding capacity of sandy soil by redistributing the soil pore sizes, leading to retain soil moisture longer with well aeration. The main purpose of the current study was to evaluate the efficiency of PAM and compost of municipal solid waste (CMSW) with two irrigation rates on the growth of rose plants grown in sandy soil.

\section{MATERIALS AND METHODS}

Two pot experiments were carried out through two successive seasons 2014/2015 and 2015/2016 at Antoniadis Research Station, Horticulture Research Institute, Alexandria, Egypt to study the response of rose plants to pre-planting incorporated on compost of municipal solid waste (CMSW) into sandy soil at two levels $(5 \%$ and $15 \% \mathrm{w} / \mathrm{w})$ and on hydrophilic polyacrylamide gel (PAM) at two levels $(0.1 \%$ and $0.2 \% \mathrm{w} / \mathrm{w})$ and at two rates of irrigation amounts $(250$ and $500 \mathrm{ml} /$ pot/3times per week). One year old seedlings of local cultivar Rosa hybrida cv. "Baccara" brought from El Minofya Governorate. The used seedlings had uniform sizes and shapes with three branches /plant and $50 \mathrm{~cm}$ in height. These seedlings were planted, on $5^{\text {th }}$ March 2014, in PVC pots of $30 \mathrm{~cm}$ diameter filled with $20 \mathrm{~kg}$ sandy soil brought from the Western Desert, $60 \mathrm{~km}$ West Alexandria city. The soil was air dried and passed through 2-mm sieve and its main chemical and physical properties were determined according to the methods outlined in page et al., (1982) and the obtained results are listed in Table1.

Two types of soil conditioners were incorporated into the sandy soil; the first was CMSW which purchased from Compost Plant for Collecting and Recycling the Solid Waste at Abees region, km 11 south east of Alexandria. Its chemical analysis was lined out by Environmental Health Research and Studies Unit, Alexandria University and recorded in Table (2).

Table 1. The main chemical and physical properties of the sandy soil

\begin{tabular}{lc}
\hline Soil Character & Value \\
\hline E.C *, dSm & \\
$\mathrm{pH}^{* *}$ & 1.33 \\
Available macronutrients, $\mathrm{mg} \mathrm{kg}^{-1}$ soil & 8.34 \\
Available N & \\
Available P & 10 \\
Available K & 2 \\
Organic matter, \% & 80 \\
C.E.C, meq/100g soil & 0.34 \\
Total carbonate, \% & 17 \\
Particles size distribution, \% & 20.35 \\
Sand & \\
Silt & 72 \\
Clay & 17 \\
Texture & 11 \\
Saturated soil paste extract. & ** 1: 2.5 soil: water suspension
\end{tabular}

Table 2. Chemical analysis of the compost of municipal solid waste (CMSW)

\begin{tabular}{|c|c|c|c|}
\hline Character & value & character & value \\
\hline $\mathrm{N}(\%)$ & 0.89 & $\mathrm{Fe}(\mathrm{mg} / \mathrm{kg})$ & 16.20 \\
\hline $\mathrm{P}(\%)$ & 0.73 & $\mathrm{Zn}(\mathrm{mg} / \mathrm{kg})$ & 0.27 \\
\hline K $(\%)$ & 0.58 & $\mathrm{NaCl}(\%)$ & 2.30 \\
\hline $\mathrm{Ca}(\%)$ & 0.54 & $\mathrm{pH}^{* *}$ & 7.11 \\
\hline $\operatorname{Mg}(\%)$ & 0.17 & Organic matter $(\%)$ & 31.22 \\
\hline $\mathrm{SO}_{4}^{-2}(\%)$ & 0.07 & $\mathrm{EC}\left(\mathrm{dSm}^{-1}\right)$ & 3.72 \\
\hline $\mathrm{Cu}(\mathrm{mg} / \mathrm{kg})$ & 0.10 & Moisture content $(\%)$ & 30.00 \\
\hline Bulk density $\left(\mathrm{kgm}^{-3}\right)$ & 0.78 & - & - \\
\hline
\end{tabular}


The compost was incorporated into the sandy soil one week pre-planting. The seedling Pots were slightly irrigated to establish a good microbial activity that allows active decomposition of organic matter. The second was polyacrylamide which PAM added to the soil just at planting time. The pots were immediately irrigated to solubilize the polymer. In order to keep the soluble polymer in the soil bulk, it was allowed to be dry for $24 \mathrm{hr}$. before starting the irrigation regime as recorded by Bowman et al., (1990). One week after planting, irrigation treatments with tap water were started. Two rates of added water were used (250 and $500 \mathrm{ml} /$ plant). Both rates were added three times per week for 24 weeks. At the end of the experimental season, the total amount of consumed water was calculated for each pot for two treatments which are 18 and $36 \mathrm{~L} /$ pot /season, respectively. The treatments were fertilized with ammonium sulphate (21\%), superphosphate $(15.5 \%)$ and potassium sulphate $(48 \%)$ fertilizers $\left(14 \mathrm{~N}-6.2 \mathrm{P}_{2} \mathrm{O}_{5}-11.6 \mathrm{~K}_{2} \mathrm{O}\right)$ as a top dressing at rate $15 \mathrm{~g} /$ plant once/month (Laurie et al., 1969). Eight flowers of each treatment, with average stem length of $25 \mathrm{~cm}$, were cut as the calyx reflexed below the horizontal position and the first two petals began to unfold (Paz, 1973). They were directly carried to the laboratory at 5.0 clock pm. and the flowers stems were re-cut under water to make a slanting surface (Carra, 1961), and directly placed in one liter tap water. The vase life of the cut flowers was calculated under standard laboratory conditions $\quad(65 \pm 5 \%$ relative humidity, $20 \pm 2 \mathrm{C}^{\circ}$ and $12 \mathrm{hr}$ light under cool white florescent lamps. Vase life was considered terminated when the flowers lost their turgidity and showed wilting (Kaltaler and Steponkus, 1974). The experimental layout was designed to provide complete randomized blocks in factorial experimental containing three replicates, each one contained eight treatments (2 organic compost levels x 2PAM levels x 2irrigation water rates). The treatment within the replicate was represented by five pots each contained one plant (Snedecor and Cochran, 1974).

\section{The measured data}

1-The vegetative growth: Plant height $(\mathrm{cm})$, leaf area $\left(\mathrm{cm}^{2}\right) /$ plant, leaves dry weight $(\mathrm{g})$, the root size $\left(\mathrm{cm}^{3}\right)$ and root fresh weight $(\mathrm{g}) /$ plant.

2-The flowering parameter: Flowering time (time from the planting to the showing color stage),flower diameter(cm),number of flowers/plant, stem length $(\mathrm{cm})$,flower vase life(day),flower duration(time from showing color to fading)and the flower dry weight $(\mathrm{g})$ were measured.
3- Plant chemical analysis: The total chlorophyll content in the leaves was determined in fresh leaves of the recent mature leaves under the flowering buds at showing color stage according to Moran and Parath (1980). The total anthocyanin content in the petals of the flowers at full opening stage was measured according to the method of Fulki and Francis (1968). The total carbohydrates content showing color stage was determined according to the method described by Dubois et al., (1956). The contents of $\mathrm{N}, \mathrm{P}$ and $\mathrm{K}$ in the leaves were determined according Westerman (1990).The same steps and techniques were exactly repeated in the second season (2015/2016) except for anthocyanin content which was measured in the $2^{\text {nd }}$ season only.

4- Soil physical and chemical analysis: Some physical quality indices of soil and also their temporal variability were evaluated. These indices were mean weight diameter (MWD) of aggregates (Kemper and Rosenau, 1986), saturated hydraulic conductivity: Ks (Amoozegar and Warrick, 1986) and total porosity: n (Danielson and Sutherland, 1986) they. Some chemical quality indices such as: $\mathrm{EC}, \mathrm{pH}$, soluble cations and anions and total carbonate, as well as exchangeable sodium percent (ESP), cation exchange capacity (CEC), organic matter, available macro- and micro-nutrients were also determined. All chemical analyses procedures were carried out according to Page et al. (1982). Percent recovery is used in cases where no chemical reaction is taking place, as in purification of a sample. It is calculated as follows: $\%$ recovery $=$ amount pure product recovered (g) / amount of crude material used (g) x 100. The normality test of data distribution was done by Kolmogorov-Smirnov test using Minitab software (MINITAB, 2003) before analyzing with ANOVA. Variance analyses of data and comparison of means by Duncan's multiple range tests was carried out using MSTAT (1988) software.

\section{RERSULTS AND DISCUSSION}

\section{1- Vegetative Growth Characteristics:}

Table (3) pointed out that the differences between the two rates of irrigation water were not significant in both seasons for most cases of the vegetative parameters. These results show that the lower rate of irrigation water was more economically and more effective in promoting the studied parameters. These findings may be interpret efficiency of the used two types of soil conditioners. These results are in accordance with those reported by Bounranis et al. (1995); Kay-Shoemake et al.(2000); Khattab etal., 
(2002) on Salvia and El Naggar et al., (2004) on Cyperuspapyrus and Sarhad and Sharif (2014). Generally, Table (3) revealed that sandy soil incorporated with the higher level of CMSW (15\%) produced the tallest rose plants, maximum leaf area/plant, maximum root size/plant compared to the lower level $(5 \%)$ in both seasons, while the heaviest leaves on dry weight basis/ plant was recorded in the $1^{\text {st }}$ season only. Stimulation the plant height as a result of adding of CMSW at the higher rate $(15 \%)$ may be due to the role of organic matter in providing the plants with their essential elements needed for growth. Similar results were recorded by Abass and Askar,(1999) on Gerbera and Abass (2003) on Polianthes tuberose. The significant promotion of the leaf area/ plant by using the organic soil conditioner in increasing number of leaves and /or size or both of them leading to maximum expansion of the produced leaves and consequently maximum leaf area should be recorded. Same trend of results was outlined by Klock (2000) on Salvia and Abass (2008) on Dahlia. The leaves dry weight was significantly increased by amending the sandy soil with the organic soil conditioner $(18.73 \mathrm{~g}$ and $25.00 \mathrm{~g}$ for the two levels $5 \%$ and $15 \%$ in the $1^{\text {st }}$ season and $20.74 \mathrm{~g}$ and $22.56 \mathrm{~g}$ for the two levels in the $2^{\text {st }}$ season) compared to the control, this may be due to role of organic matter after decomposition in providing the plants with more releasing of the macro- and microelements in available form to be taken up by the plant roots and allow good accumulation of elements in the leaves, thus heavier leaves dry weight was associated with the higher addition of the organic soil conditioner (Shanks and Gouin, 1985) on Rose. These results are in harmony with those reported by Smith (1993) on petunia; Cox (1995) on Salvia and Abass and Askar (1999) on Gerbera plant. Table (3) also proved that the CMSW had stimulatory effect on the root size/plant. The maximum size was associated with the higher addition of CMSW (57.34g and 62.99g for two levels in the $1^{\text {st }}$ season and $55.17 \mathrm{~g}$ and $64.10 \mathrm{~g}$ for two levels in the $2^{\text {nd }}$ season) which may be reflected in active nitrogen assimilation and increased cell division, consequently more assimilates accumulation. Table (3) also show that using CMSW at the two levels significantly increased the plant height in the first season $(112.05 \mathrm{~cm}$ and $118.28 \mathrm{~cm}$ for the two levels, respectively), while the root fresh weight/plant was increased in both seasons (Table 3). Also, adding of PAM gradually increased the studied vegetative parameters as polymer level increased, but these increases were not significant. Stimulatory effect of PAM on the plant height may be attributed to the synergistic effect at the added suitable level $(0.2 \%$ $\mathrm{w} / \mathrm{w})$. These findings are in agreement with the results obtained by Klock (2000) and Khattab et al., (2002) on Salvia splendens.

\section{2- Flowering Growth Characteristics:}

Table (4) showed no significant differences between the used two irrigation rates for the most studied flowering parameters with only one exception, the flowering time in the $2^{\text {nd }}$ season which recorded a significant difference. These results revealed that using rate $250 \mathrm{ml} / \mathrm{plant} / 3$ times per week $(18 \mathrm{~L} / \mathrm{plant} / \mathrm{season})$ in the $1^{\text {st }}$ or rate $500 \mathrm{ml} /$ plant $/ 3$ times per week $\left(36 \mathrm{~L} /\right.$ plant/season) in the $2^{\text {nd }}$ recorded values approximately nearly to each other in both season for the most studied flowering characteristics. These findings show that the lowest irrigation rate proved to be more economical than the highest rate. Table (4) show that incorporation the CMSW into the sandy soil at level of $15 \% \mathrm{w} / \mathrm{w}$ resulted in significant reduction in the time that required to reach the flowering stage of rose plant (45.99 day), a significant increase recorded in flower diameter $(8.83 \mathrm{~cm})$ as well as in the flower dry weight $(3.26 \mathrm{~g})$ in the $1^{\text {st }}$ season only compared to the lowest level of compost $(5 \% \mathrm{w} / \mathrm{w})$. While it was clarified to be more beneficial in both seasons for the vase life 7.49 and 7.50 day respectively. Numbers of flowers/plant were 7 and 5 respectively, stem lengths were 32.34 and $42.07 \mathrm{~cm}$, respectively and duration periods were 6.27 and 6.49 day, respectively. The highest compost level $(15 \% \quad \mathrm{w} / \mathrm{w})$ significantly stimulated the flowering parameters in both seasons. These results interpret that the efficiency of pre-planting organic compost incorporation into the sand plays a vital role in providing the plants with their needs from elements and micro-elements. As the organic matter decomposes, it becomes chemically altered, this change gives it a negative charge that attracts and holds inorganic elements such as $\mathrm{K}, \mathrm{Ca}$ and $\mathrm{Mg}$ in available form to be absorbed by the plant roots (Wallace and Wallace, 1986 and Shakoor et al , 2012). Process of feeding plant with nutrients reflected more accumulation of biosynthates in the plant tissues that encourage more carbohydrate accumulation reflected in significant prolongation of vase life as illustrated by Abass (2003) on Rose plant. The active role of the organic soil conditioner in improving hydro-physicchemical properties of the sandy soil and increasing water holding capacity of the soil was reported by (Askar, 1988). The organic matter absorbs water like sponge and increases soil moisture for a long time and improves water use efficiency (WUE) as reported by Wallace and Wallace, (1990) and Abbas (2013). These finding are in agreement with those reported by Abass and Askar, (1999) on Gerbera; Khattab et al., (2002) on Salvia. Using the polymer of PAM showed significant 


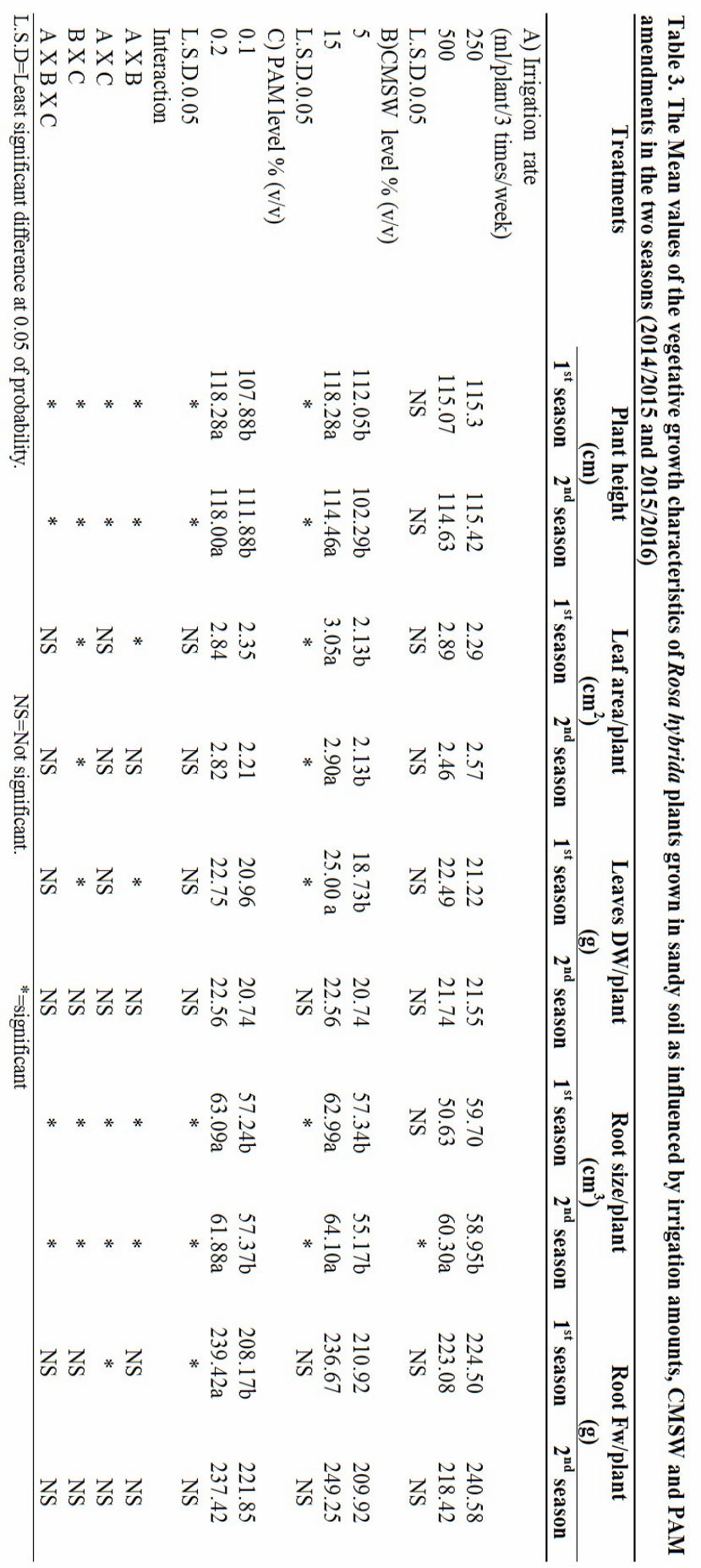




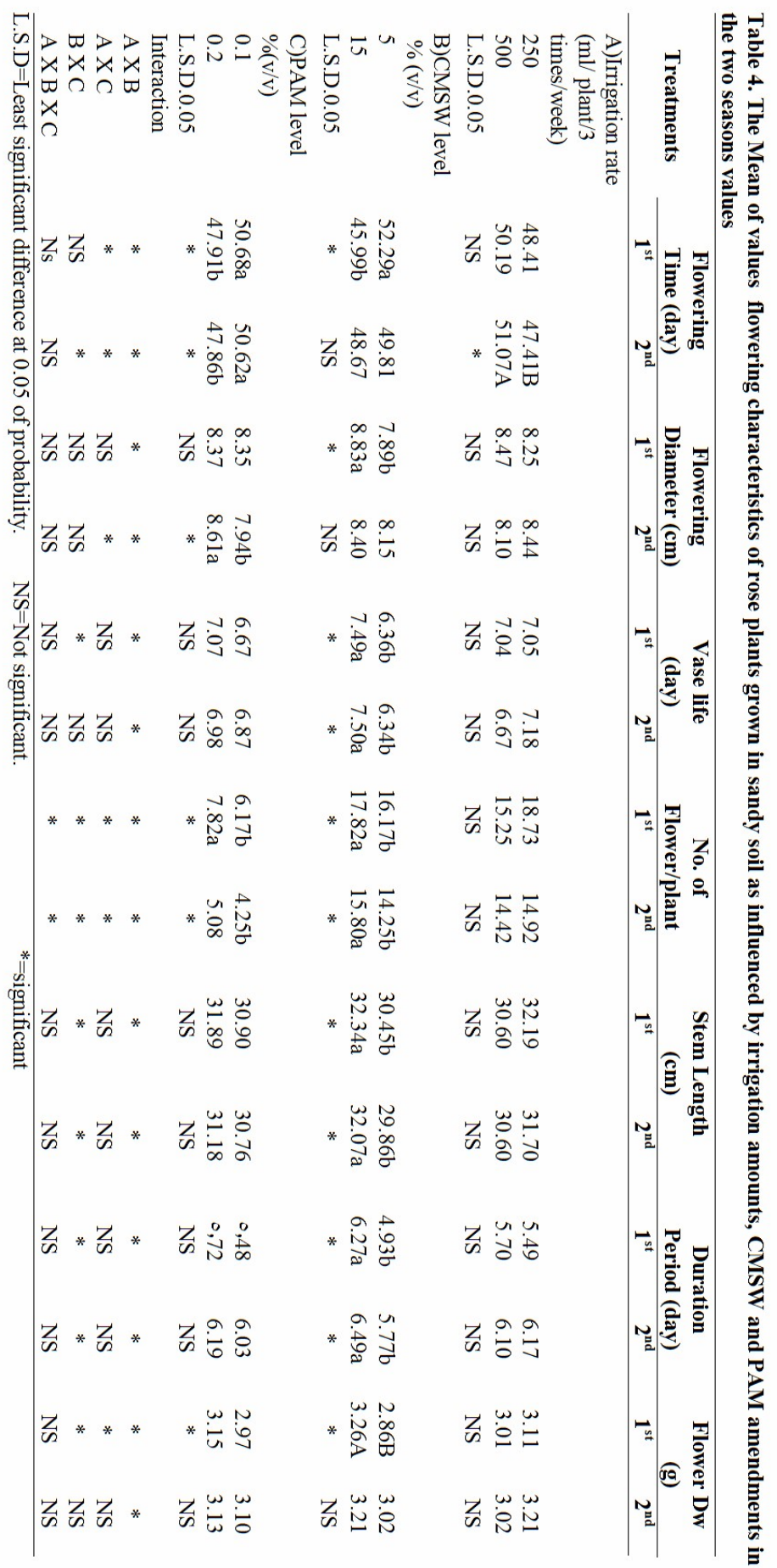


reduction in time required to flowering stage and increasing in number of flowers/plant in both seasons at the higher levels $(0.2 \% \mathrm{w} / \mathrm{w})$ while in only first season the increase was recorded for the flower diameter as well as flower dry weight. The promotional effect of PAM at the level $(0.2 \% \mathrm{w} / \mathrm{w})$ may be due to its efficiency in keeping water in more than one state (bound and free), the free water contain solution in chemical equilibrium with the external solution compensate the absorbed elements (Deboot, 1990 ; Askar, 1991 and Bres and Waston, 1993). In addition, the active role of PAM in redistributing the soil pores size, leading to retain moisture longer with well aeration and less evaporation (Lentez et al. 2001). These findings are in agreement with those recorded by Khattab et al., (2002) on Salvia splendense and Wafaa and Eid, (2016).

\section{3- The Chemical Constituents}

Table (5) showed that $\mathrm{N}$ content significantly increased in the leaves as a result of the influence of incorporation of CMSW into the soil at the higher level $(15 \% \mathrm{w} / \mathrm{w})$ in both seasons. The P content significantly increased as a result of the lower irrigation rate $(250 \mathrm{ml} /$ plant/three times per week). The $\mathrm{K}$ content significantly increased at the level of $15 \% \mathrm{w} / \mathrm{w}$ of the CMSW in the $2^{\text {nd }}$ season only (Table 5). The total chlorophyll and the carbohydrates contents significantly increased as a result of using the compost at the higher level $(15 \% \mathrm{w} / \mathrm{w})$ in the both two seasons. Anthocyanin content in the petals was increased with increasing the level of each one of the used soil conditioners. Maximum content of the pigment was recorded at the highest level of the compost $(34.48 \mathrm{mg} / \mathrm{g}$ ) compared to the lowest level. There was a gradual increase in the content of the pigment as a result of increasing the level of the polymer, but this increasing was not significant Table (5). Enhancing accumulation of the pigment may be due to the active metabolism process as a result of releasing macro-elements and micro-elements needed for plant nutrition and pigment formation. These findings proved efficiency of organic compost at the suitable level in improving the hydro-physic-chemical properties of the sandy soil via increasing its fertility through high cation exchange capacity (CEC) that enhancing soil infiltration rate and improving water holding capacity (Askar, 1988 and Choudhary et al., 1998). Treatment with polyacrylamide gel (PAM) significantly increased $\mathrm{P}$ content, the total chlorophyll and carbohydrates in the leaves in both seasons. The higher level $(0.2 \% \mathrm{w} / \mathrm{w})$ proved more superiority compared to the lower level in promoting these chemical constitutes. As shown in Table (5), PAM acted on enhancing the availability of $\mathrm{N}$ and $\mathrm{P}$ in both seasons and agreed with the findings by (De boodt, 1979 and 1990). Thus the metabolic process and biosynthesis were significantly increased with the level of $15 \% \mathrm{w} / \mathrm{w}$ of CMSW in the $2^{\text {nd }}$ season Table (5). Similar trend of results were found by Mostafa and Askar (1997) on Dianthus; Abass and Askar, 1999 on Gerbera; Bjorneberg et al.,(2000) and Khattab et al.,(2002) on Salvia spendense.

\section{4- Soil physical and chemical parameters:}

1. Mean weight diameter (MWD) of soil aggregates: Fig. 1 shows that both two high application rates of PAM and CMSW significantly increased MWD compared with the control. This increase was about 127 and $83 \%$ for two high application rates of PAM and CMSW, respectively, relative to the control. Although negatively charged polymers as anionic PAM that have the same charge as clay surfaces tend to be repelled, anionic polymers can still be attached to clay through bridging between the anionic groups and negatively charged clay surfaces in the presence of polyvalent cations (Inyang and Bae, 2005). Similarly, Levy and Miller (1999) found that the application of anionic PAM on a sandy loam soil significantly increased MWD using wet sieving method relative to the control.

2. Saturated hydraulic conductivity (Ks): Fig. 2 shows that high application rate of PAM significantly increased Ks $14.5 \%$, compared with CMSW. The highest Ks value $\left(0.6 \mathrm{~cm} \mathrm{hr}^{-1}\right)$ was obtained for PAM treatment at higher used rate and it significantly differed from Ks value at higher used rate of CMSW. It seems that PAM by creating water stable aggregates (Fig. 1) prevented pore clogging in the examined fine-textured soil and finally increased Ks. Neyshabouri et al. (2006) found that adding 50 $\mathrm{mg} \mathrm{L}^{-1}$ PAM to a sandy loam soil significantly increased $\mathrm{Ks}$ from 4.42 to $8.89 \mathrm{~cm} \mathrm{hr}^{-1}$. The increase of Ks in PAM treated fine-textured soils has also been reported by Bryan (1992), Santos and Serralheiro (2000), and Ghorbani et al. (2009).

3. Total porosity (n): Fig. 3 shows that application of PAM significantly increased the total porosity (n) compared with the control and CMSW. The total porosity of PAM treated soil was higher than that of the control by 8.75 and $7.75 \%$ as a result of PAM application rates of 0.1 and $0.2 \%$, respectively. It seems that PAM, by creating coarse and stable aggregates, had increased soil volume and decreased soil bulk density $(\mathrm{Db})$, and consequently increased $\mathrm{n}$. These findings agree with the results of Sadegian et al. (2006) who reported that PAM application at the concentration of $50 \mathrm{mg} \mathrm{L}^{-1}$ significantly decreased $\mathrm{D}_{\mathrm{b}}$ and increased $\mathrm{n}$ of a sandy loam soil. 


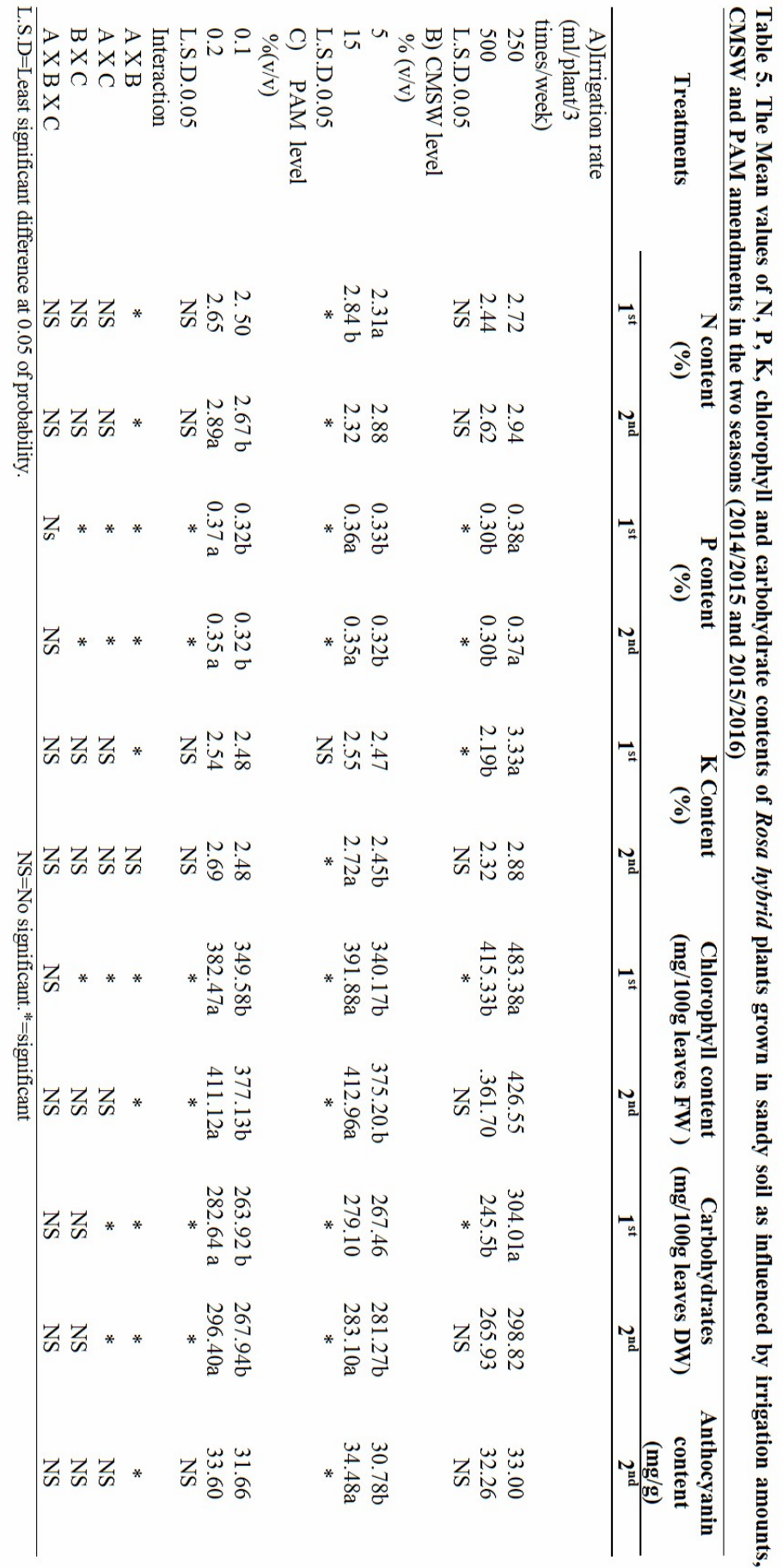


According to Fig. 3, $\mathrm{n}$ value was significantly decreased than that from in the control treatment due to break down of aggregates, while $\mathrm{n}$ was not changed in PAM treatments because of the formation of stable aggregates. Asghari et al. (2009) reported that PAM application in a sandy loam soil modified pore size distribution by the significant increase of micropores $(\mathrm{d}=30-75 \mu \mathrm{m})$ relative to the control. Seyed et al. (2010) showed that adding $0.6 \%(\mathrm{w} / \mathrm{w})$ of a superabsorbent polymer on a clay soil increased capillary and aeration porosity by 28.8 and $33.33 \%$, respectively, relative to the control.
3. Soil pH, EC, O.M and CEC: Figure 4a showed that there are differences in the $\mathrm{pH}$ of treated soils compared to control. On the contrary, the EC of treatments were no obvious differed compared with the control (Fig. 4b). This indicates that exchangeable cations and anions are present in PAM and organic compost (CMSW) can influence properties such as soil acidity and alkalinity, nutrient availability and microbial activity. Soil $\mathrm{pH}$ affects all chemical, physical and biological properties of soils (Brady and Weil, 2002).

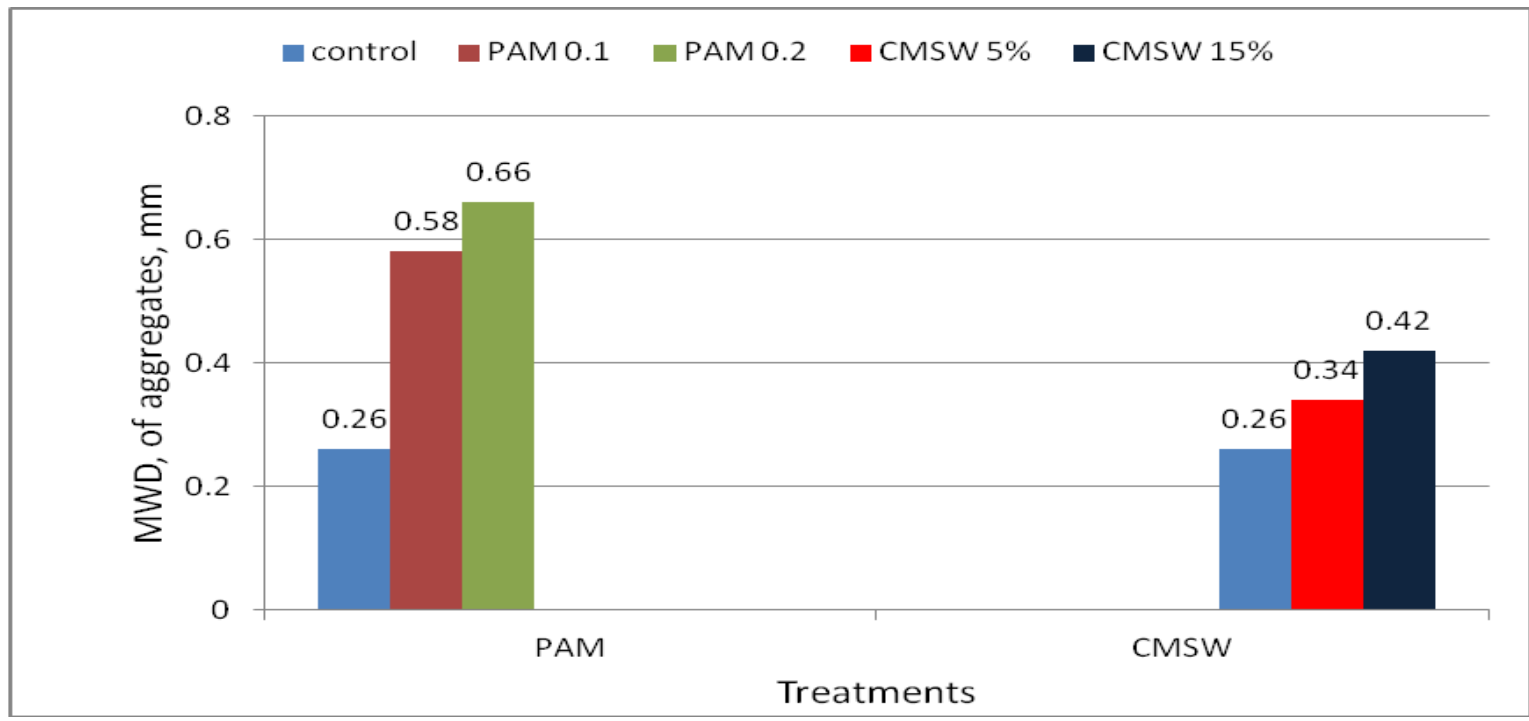

Figure 1. Effect of PAM and CMSW levels on mean weight diameter (MWD) of soil aggregates (mm)

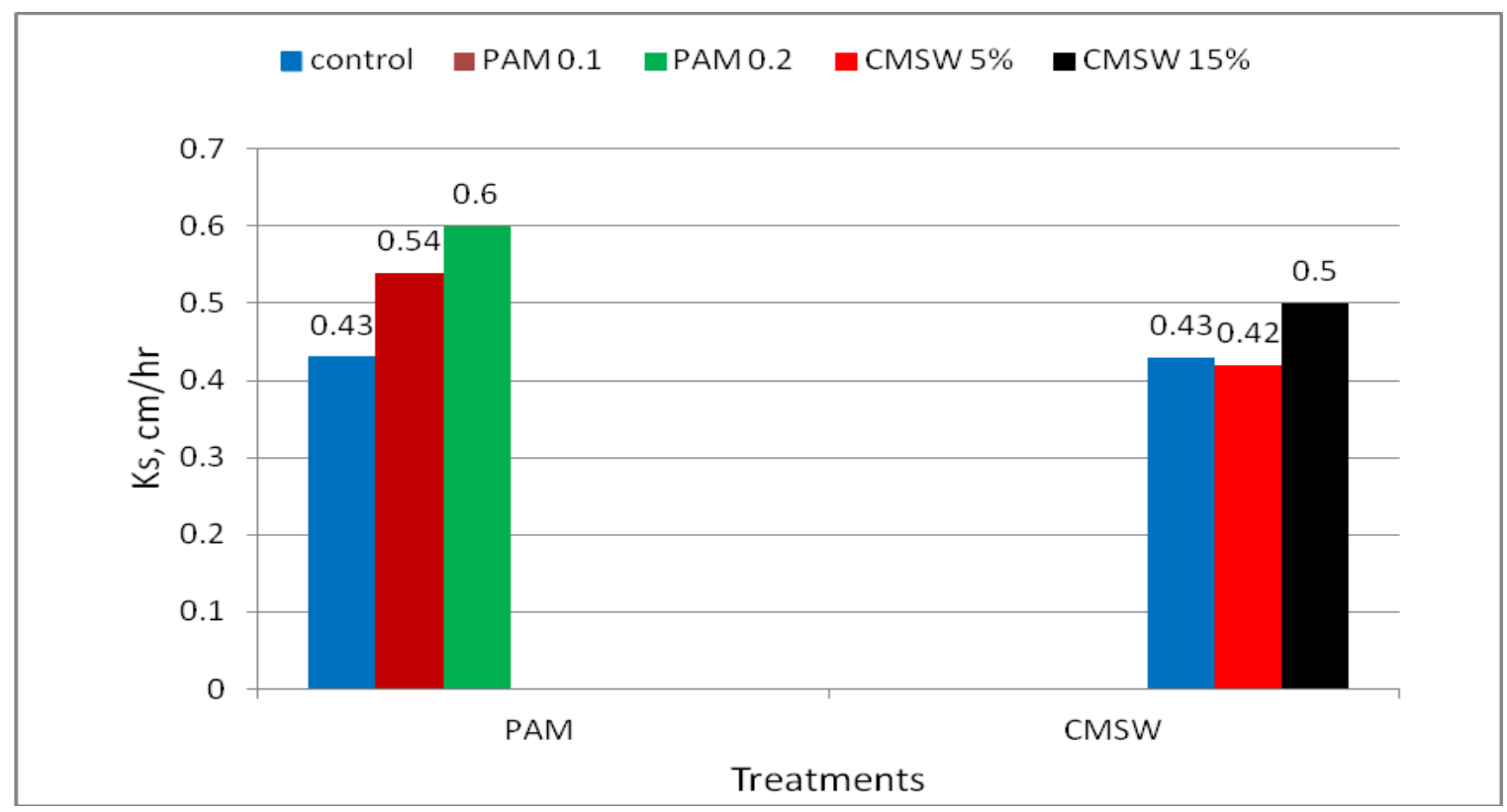

Figure 2. Effect PAM and CMSW levels on saturated hydraulic conductivity (Ks) 


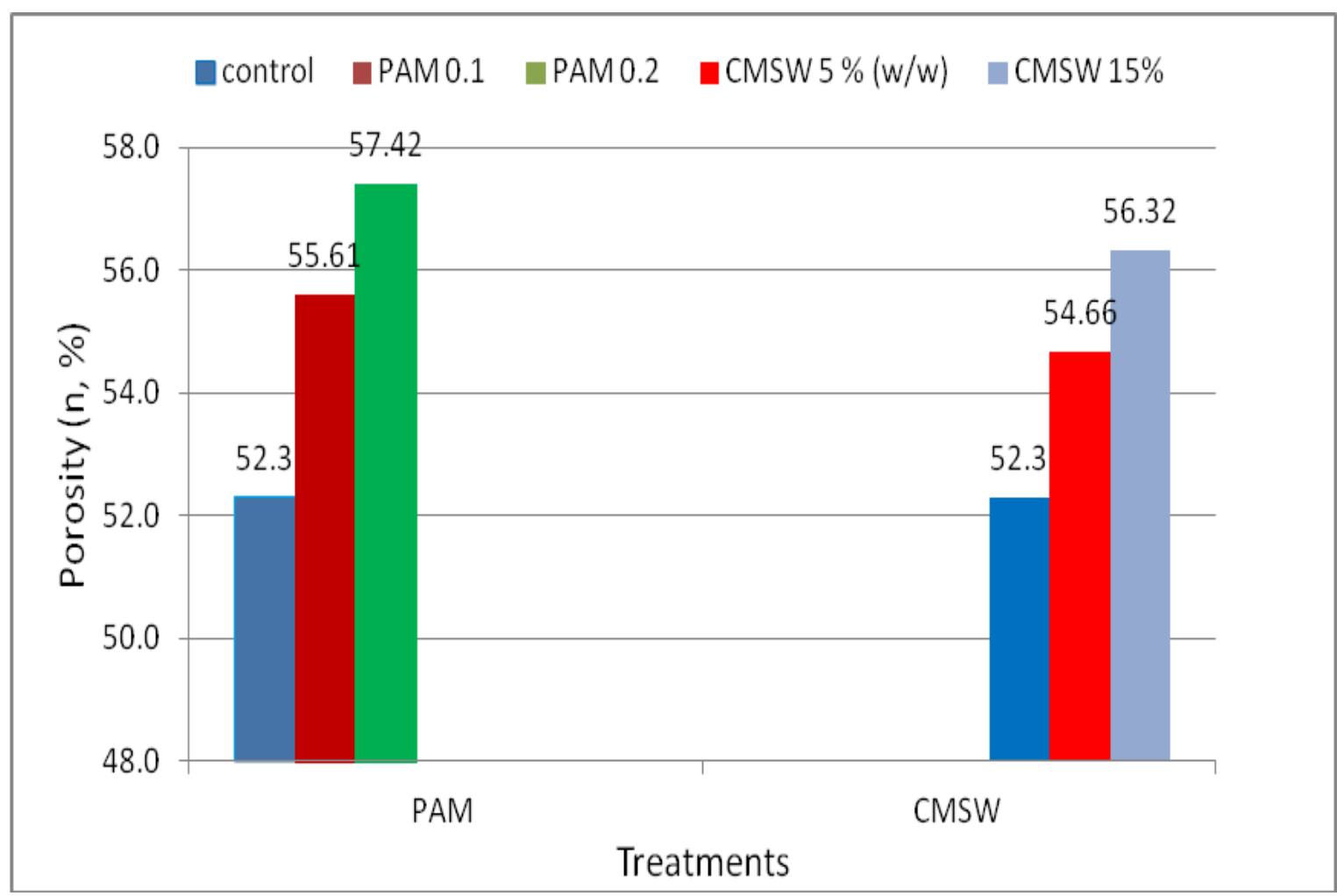

Figure 3. Effect Polyacrylamide PAM and CMSW levels on total porosity (n)

In PAM $0.1 \%$ and $0.2 \%(\mathrm{w} / \mathrm{w})$ treatments, soil $\mathrm{pH}$ values decreased compared to CMSW treatments and the control. The $\mathrm{pH}$ decreases were particularly pronounced with both PAM treatments compared with the control. However, the $\mathrm{pH}$ values increased particularly with both CMSW treatments compared with the PAM treatments and decreased particularly compared with the control. Overall, $\mathrm{pH}$ values generally decreased in response to PAM and CMSW treatments compared with control. The PAM treatments had similar effects on soil. Soil $\mathrm{pH}$ can affect $\mathrm{CEC}$ and AEC by altering the surface charge of colloids. A higher concentration of $\mathrm{H}^{+}$(lower $\mathrm{pH}$ ) will neutralize the negative charge on colloids, thereby decreasing CEC and increasing AEC. The opposite occurs when $\mathrm{pH}$ increases. It is obvious from (Fig. 4c), PAM treatments, that CEC sharply increased compared with CMSW treatments. The O.M has a negative effect on PAM sorption that could be attributed to the reduction of accessible sorption sites by cementing inorganic soil components to form aggregates and to the enhancement of electrostatic repulsion between PAM and soil surface by its negatively charged functional groups.

\section{5- Soil elements:}

This study assessed also the effects of PAM on major nutrients $\left(\mathrm{NO}_{3}-\mathrm{N}, \mathrm{NH}_{3}{ }^{-} \mathrm{N}, \mathrm{T}-\mathrm{N}, \mathrm{PO}_{4}-\mathrm{P}, \mathrm{T}-\mathrm{P}, \mathrm{K}\right.$, $\mathrm{Ca}$, and $\mathrm{Mg}$ ) in soils. Decreases in the loss of soluble nutrients, particularly $\mathrm{NH}_{3}-\mathrm{N}, \quad \mathrm{PO}_{4}-\mathrm{P}$ and $\mathrm{T}-\mathrm{P}$, are observed in PAM and CMSW treatments (Fig. 5). In contrast, PAM treatments have no effect on nitrate. The mass recovery rate for $\mathrm{NO}_{3}-\mathrm{N}$ did not reach $100 \%$ due to the interaction of $\mathrm{NO}_{3}-\mathrm{N}$ with soil, indicating that nutrient components are irreversibly absorbed within soil pore spaces. Other nutrients $\left(\mathrm{NH}_{3}-\mathrm{N}, \mathrm{T}-\mathrm{N}, \mathrm{T}-\mathrm{P}\right.$, and $\mathrm{PO}_{4}-\mathrm{P}$ ) also showed less than $100 \%$ mass recovery rates. In Figure5, the breakthrough curves of nitrate as nitrogen $\left(\mathrm{NO}_{3}-\mathrm{N}\right)$ with PAM and $\mathrm{CMSW}$ treatments were compared with the breakthrough curve of control. As PAM treatments, they lead to a low peak concentration and a late tail of the breakthrough curve. This indicates that PAM application affected solute transport and retention in soil. However, the addition of PAM and CMSW treatments to soil changes the charge of the soil surface, which becomes somewhat negative (Lu et al., 2002). This explains the high solubility and mobility of $\mathrm{NO}_{3}-\mathrm{N}$ with application of PAM and CMSW. A similar pattern was seen for T-N (Fig. 5). At high PAM concentration, the recovery rates were increased $9.2 \%$ for $\mathrm{NO}_{3} \mathrm{~N}$ and $11.5 \%$ for $\mathrm{T}-\mathrm{N}$, respectively. In contrary, the recovery rates for $\mathrm{NH}_{3}-\mathrm{N}$, $\mathrm{PO}_{4}-\mathrm{P}$ and T-P were decreased to $18.0 \%, 48.3 \%$, and $9.5 \%$, respectively. 


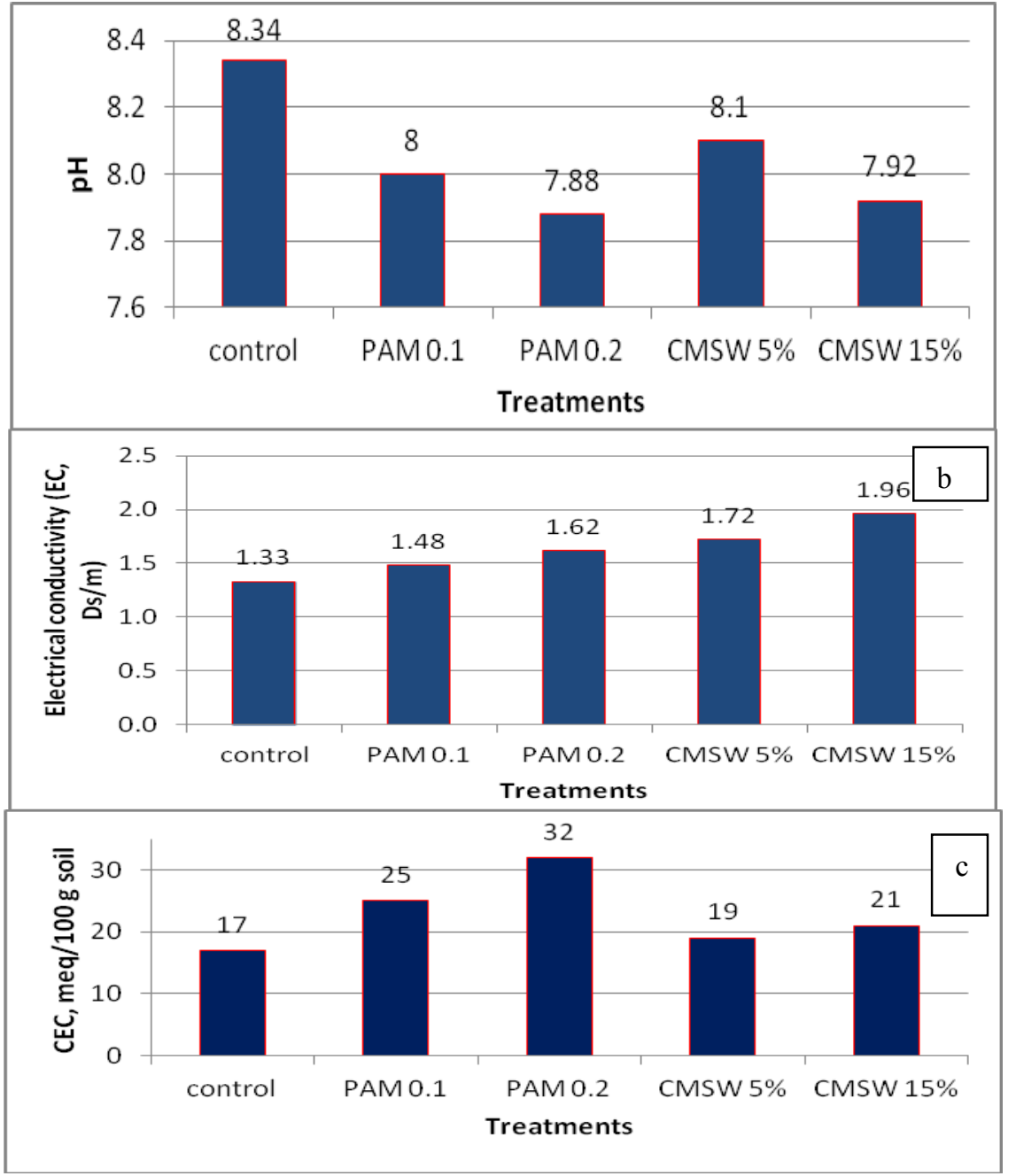

Figure 4. Effect of PAM and CMSW treatments on Soil pH (a), EC (b) and CEC (c)

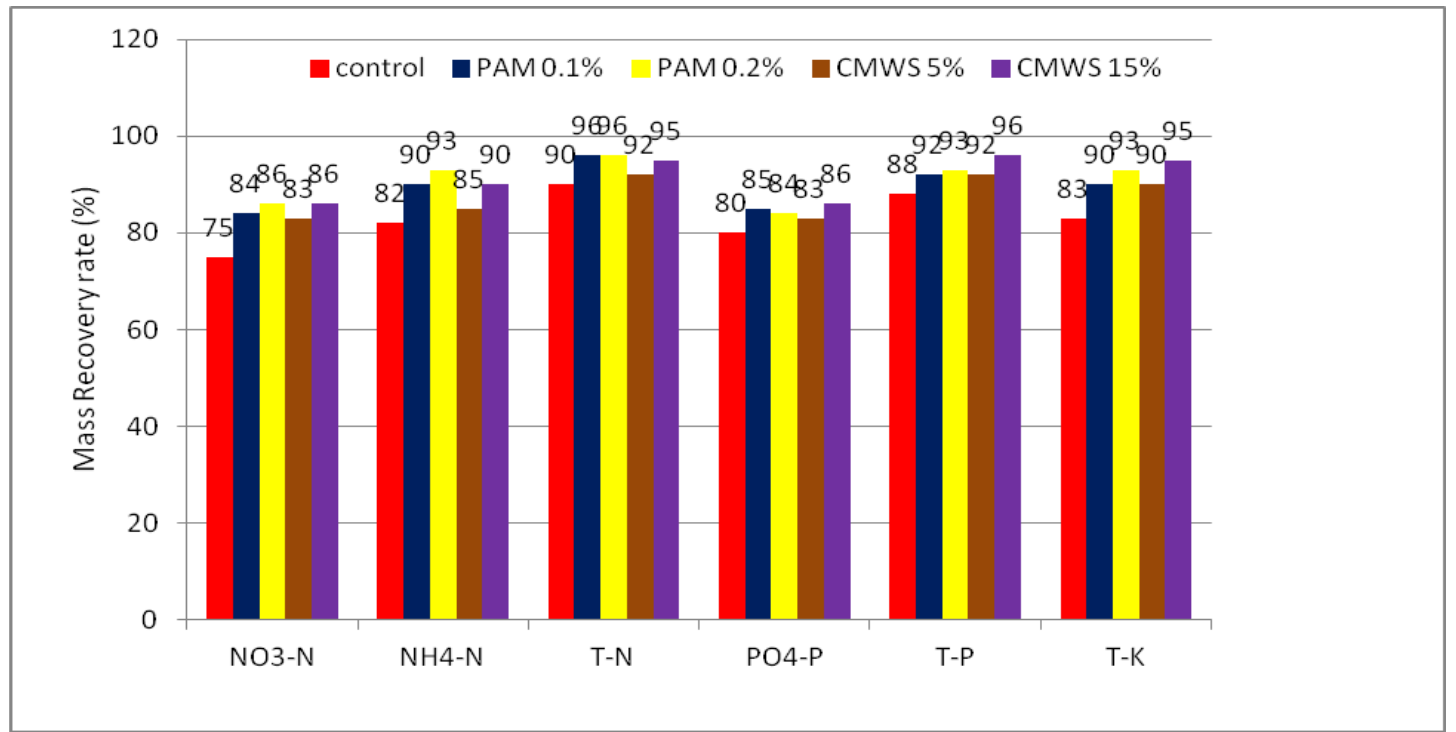

Figure 5. Mass recovery of major nutrients at different concentrations of PAM and CMSW 


\section{CONCLUSION}

Applying CMSW at high level (15\%) to a soil surface produced the tallest rose plants, maximum leaf area/plant, maximum root size/plant compared to the lower level (5\%) in both seasons, while the heaviest leaves on dry weight basis/plant was recorded in the $1^{\text {st }}$ season only. Also, the leaves dry weights and maximum root size were associated with higher addition of CMSW in the two seasons. Using of CMSW at two levels significantly increased the plant height in the first season and the root fresh weight/plant was increased in the both seasons. It is found that there were no significant differences between the used two irrigation rates for the most studied flowering parameters with only one exception i.e., the flowering time in the $2^{\text {nd }}$ season which recorded a significant difference and clarified that lowest the irrigation rate $(250 \mathrm{ml} / \mathrm{plant} / 3$ times per week) proved to be more economical than the highest rate. Also, incorporation the CMSW into the sandy soil at level of $15 \% \mathrm{w} / \mathrm{w}$ of resulted in a significant reduction in the time that required to reach the flowering stage of rose plant (45.99 day), a significant increase recorded in flower diameter as well as the flower dry weight in the $1^{\text {st }}$ season only compared to the lowest level of CMSW $(5 \% \mathrm{w} / \mathrm{w})$. Therefore, it was clarified to be more beneficial in both seasons of the study for the vase life 7.49 and 7.50 day respectively. Number of flowers/plant, stem length and duration period were increased by using the higher level of CMSW $(15 \%$ $\mathrm{w} / \mathrm{w}$ ) in both seasons. The $\mathrm{N}$ content significantly increased in the leaves as a result of treatment with the higher level of CMSW $(15 \% \mathrm{w} / \mathrm{w})$ in both seasons, while maximum $\mathrm{P}$ concentration was significantly increased as a result of the lower treatment rate (250 $\mathrm{ml} /$ plant/three times per week). The $\mathrm{K}$ content was significantly increased at the level $(15 \% \mathrm{w} / \mathrm{w})$ of the compost (CMSW) in the $2^{\text {nd }}$ season only. The total chlorophyll and the carbohydrates content was significantly accumulated as a result of using the compost at the higher level $(15 \% \mathrm{w} / \mathrm{w})$ in the both two seasons. Anthocyanin content in the petals was increased with increasing the level of each one of the used soil conditioners. Also, adding of PAM treatments gave gradually increased the studied rose vegetative parameters as polymer level increased in the sandy soil but these increases were not significant. Stimulatory effect of PAM on plant height can be attributed to the synergistic effect at the suitable level $(0.2 \% \mathrm{w} / \mathrm{w})$. Usin PAM polymer showed significant decrease in time required to flowering stage and increasing in number of flowers/plant in both seasons at the higher levels $(0.2 \%$ $\mathrm{w} / \mathrm{w})$ while in only first season the increase was recorded for the flower diameter as well as flower dry weight. Soil conditioner polyacrylamide gel (PAM) significantly increased $\mathrm{P}$ content, the total chlorophyll and carbohydrates in the leaves in both seasons. The higher level $(0.2 \% \mathrm{w} / \mathrm{w})$ proved more superiority compared to the lower level $(0.1 \% \mathrm{w} / \mathrm{w})$ in promoting the mentioned chemical properties. Both two high application rates of PAM and CMSW significantly increased the mean weight diameter (MWD) compared with the control. High and low application rates of PAM significantly increased the total porosity (n) compared with the control and CMSW. The total porosity of PAM treatments was still higher than the control by 8.75 and $7.75 \%$, respectively. $\mathrm{pH}$ values generally decreased in response to PAM and CMSW treatments compared with control, while, the EC of treatments were no obvious differed compared with the control. As a result of from PAM treatments the CEC sharply increased compared with CMSW treatments. Decreases in the loss of soluble nutrients, particularly $\mathrm{NH}_{3}-\mathrm{N}, \mathrm{PO}_{4}-\mathrm{P}$ and $\mathrm{T}-\mathrm{P}$, are observed in PAM and CMSW treatments. In contrast, PAM treatments have no effect on nitrate. In summary, It could be recommended to grow rose plants in sandy soil under reclamation amended with pre-planting organic compost CMSW at level $(15 \% \mathrm{w} / \mathrm{w})$ and the hydrophilic polymer (PAM) at level $(0.2 \% \mathrm{w} / \mathrm{w})$ with irrigation rate at $250 \mathrm{ml} / \mathrm{plant} / 3$ times per week.

\section{REFERENCES}

Abass, R. A. 2003. Response of Polianthes tuberose L. to sewage sludge addition to the newly reclaimed soils. Alex.Sci Exch. 24(3):283-297.

Abass, R. A. 2008. Influence of potassium, organic and biofertilizer on growth,flowering and chemical constituents of Dahlia pinnata plant. The Fourth Conf. of Sustain. Agric. Develop. Fec. of Agric., Fayoum Univ. 20-22 Oct.pp. 181- 192.

Abass, R. A. and F.A. Askar. 1999. Effect of gibberellic acid and sewage sludge on growth, flowering, chemical content and vase life of Gerbera jamesonii, hook grown on sand soil. Ad. Agric. Res. 4(3):133-145.

Abbas, Z.M., Khalil, F.A.F. and M.T.wafaa. 2013. Influence of water regimes and soil conditioners on yield, yield components and water utilization efficiency of Egyptian clover variety (Fahl). J. Plant Production, Mansoura Univ. 4(11):1675-1690.

Abd El-Hady, M. and E. I. Eldardiry 2012. Sustainable reclamation of newly and natural zeolite on sandy soil properties and productivity of crops. Top class Jour. of Agric. Res. 1: 22-28.

Abd-Ella, E. K. Eman. 2011. Effect of soil conditioners and irrigation level on growth and productivity of pomegranate trees in the new reclaimed region.Alex. Sci. exchange J. 32(4):550-575. 
Amoozegar, A. and A.W. Warrick. 1986. Methods of soil analysis. Number 9 (Part1). Physical and Mineralogical Methods. Second Edition. American Society of Agronomy, Inc. Soil Sci.Soc. Am, Inc. Publisher: Madison, Wisconsin, USA.

Askar, F.A. 1988. Suitability of soil conditioners for desert and cultivated soil in Egypt. Inter. Symp. Soil conditioners, Egypt.pp.133-142.

Askar, F.A. 1991. Root-shoot growth of fenugreek in the presence of hydrolyzed Polyacrytonitrile in sandy and clay soil. $1^{\text {st }}$ Arab into conf. on polymers and their application. El Mansoura University, pp.91-102.

Asghari, S., M.R. Neyshabouri, F. Abbasi, N., Aliasgharzad and S. Oustan. 2009. the effects of four organic soil conditioners on aggregate stability, pore size distribution, and respiration activity in a sandy loam soil. Turk. J. Agric. For. 33: 47-55.

Ayman, A. M. A., A. N. Nomier, A.S.A. Hassan and M. A. Hassan .2015. Effect of different irrigation levels and some soil conditioner treatments on growth and productivity of pomegranate trees cv. Manfalouty. Zagazig J. Agric. Res. 42(5) pp: 87 - 98.

Bjorneberg, L.,K. Alsae and T. Westerman. 2000. Controlling sprinkler irrigation runoff, erosion and phosphorus loss with straw polyacrylamide. Translation of the ASAE.43: 1545-1551.

Bouranis, D.L., A.G. Theodoropoulos and J.B, Drossopoulos. 1995. Designing synthetic polymers as soil conditioners. Comm. Soil Sci. and Plant Analysis. 26(9-10): 14551480.

Bowman, D., E. Richard and L. Paul. 1990. Fertilizer salts reduce hydration of polyacrylamide gel and affect physical properties of gel-amended container media. J.Amer. Soc. Hort. Sci. 115: 382-386.

Brady, N.Cand, R.R., Weil. 2002. The Nature and Properties of Soil, 13th edn. Springer, Netherlands.

Bres, W. and A. Weston. 1993. Influence of gel additives on nitrate, ammonium and water retention and tomato growth in a soilless medium. Hort. Sci., 287: 1005-1007.

Bryan, R.B. 1992. The influence of some soil conditioners on soil properties: Laboratory tests on Kenyan soil sample. Soil Technol. 5:225-247.

Carra, P. 1961. Experiments on the cold storage of cut flowers. Hort. Abst. 31:1053.

Choudhary, I., M. Al - Omran and A. Shalaby. 1998. Physical properties of sandy soilaffected by soil conditioner under wetting and drying cycles. Sultan Qaboos University J. Sci. Res.-Agric. -Sci. 3:69-74.

Cox, A. 1995. Pelletized sewage sludge as a fertilizer for containerized plants: plant growth and nitrogen losses. J. Plant Nutri. 18:2783-2795.

Danielson, R.E. and P.L. Sutherland. 1986. Methods of Soil Analysis. Number 9 (Part 1). Physical and Mineralogical Methods. Second Edition. American Society of Agronomy, Inc. Soil Sci. Soc. of Am., Inc. Publisher: Madison, Wisconsin, USA.
De Boodt, M., C.Van Den Berghe, and D.Gabriels. 1979. Fertilizer losses associated with soil erosion. In Soil physical properties and crop production in the tropics, $\mathrm{pp}$. 455-64.

De Boodt, M.F. 1990.Application of polymeric as physical soil conditioner. W: Soil colloids and their associations in aggregates (re. M.F. De Boodt, M. Hayes, A. Herbillon), NATO ASI Series, Ser. B: Physics, 215, Plenum Press, New York, 517-556, 1990.

Dorraji, S. S., A. Golchin, and S. Ahmadi. 2010. The Effects of Hydrophilic Polymer and Soil Salinity on Corn Growth in Sandy and Loamy Soils. Clean Soil Air Water, 38(7): 584-591.

Dubois, M., K. Gills, J. Hamilton and F. Smith. 1956. Colorimetric method for determination of sugars and related substances. Annal. Chem., 281-350.

El-Naggar, A.A.M., A.H. El-Naggar and F.M. El-Fawkhry .2004. Physiological studies on growth and flowering of Cyperus papyrus, L.1- Effect of growing media and water requirements. Alex. J. Agric. Res 49(3):39-105.

Fuleki, T. and F.J. Francis. 1968. Quantitative methods of anthocyanin: 1- Extraction and determination in cranberries. J. Food Sci., 33(1):72-82.

Ghorbani Vaghei, H., H. A.Bahrami, M.H.Ghaffarian Mogharrab, H.Shahab, F. Taliei Tabari. 2009. Efficiency of anionic polyacrylamide in the increase of soil infiltration rate. Iran. J. Soil Water Res. 39 (1): 77-84. (in Persion) Inyang, H.I., Bae, S., 2005. Polyacryamide sorption opportunity on interlayer and external pore surfaces of contaminant barrier clays.

Hassan ,A .Z. A and A. M .Mahmoud. 2013.The combined effect of bentonite and natural zeolite on sandy soil properties and productivity of some crop. Top class J. of Agric., 1: 33-28.

Holliman, P. J., J. A. Clark, J. C. Williamson and D. L. Jones. 2005. Model and fieldstudies of the degradation of cross-linked polyacrylamide gels used during the revegetation of slate waste. Sci. Total Environ, 336(1- 3): 13-24.

Huettermann, A., L. J. B. Orikiriza and H. Agaba. 2009. Application of superabsorbent polymers for improving the ecological chemistry of degraded or polluted lands. Clean Soil Air Water, 37(7): 517-526.

Inyang, H.I., and S. Bae. 2005. Polyacryamide sorption opportunity on interlayer and external pore surfaces of contaminant barrier clays. Chemosphere. 58: 19-31.

Islam, M. R., X. Xue, S. Mao, C. Ren, A. E. Eneji, and Y. G. Hu. 2011. Effects of water-saving super absorbent polymer on antioxidant enzyme activities and lipid peroxidation in oat (Avena sativa L.) under drought stress. Journalof the Science of Food and Agriculture.91(4): 680-686.

John, S.H. and A.W. David. 2000. Soil conditioners. North Central Regional Committee, Extension Publication 295: NCR-103, Non-Traditional Soil Amendments and Growth Stimulants. In cooperation with NCR Educational Materials Project 
Jouyban,Z. and S.G. Moosavi. 2014.Study of effects of different levels of irrigation interval, nitrogen and superabsorbent on seed yield and morphological traits of Sesame. Australian J. of Basic and Apple. Sci. 5:13171323.

Kaltaler, R.E.L. and P.L. Steponkus 1974. Uptake and metabolism of sucrose in cut roses. J. Am. Soc. Hort. Sci. 490-493.

Kay-Shoemake,E. Westwood, L. Kilpatrick and K. Haarri. 2000. Exchangeable ammonia and nitrate from different nitrogen fertilizer preparations in polyacrylamide- treated and untreated agricultural soils. Biology and Fertility of Soils. 31:245-248.

Kemper, W.D. and R.C. Rosenau. 1986. Methods of Soil Analysis. Number 9(Part1) Physical and Mineralogical Methods. Second Edition. American Society of Agronomy, Inc. Soil Science Society of America, Inc. Publisher: Madison, Wisconsin, USA.

Ketterings, Q., S. Reid and R.Rao. 2007 .Cation Exchange Capacity (CEC), Agronomy Fact Sheet Series (22). Cornel University Cooperative Extension.

Khattab, M., Ola El Shennawy, M. Mostafa and N.Gomae. 2002. Effect of some soil conditioners and irrigation rates on the growth and flowering of Salvia splendense plants. Alex.J. Agric. Res. 47 (2): 163-172.

Klock, K.A. 2000. Comparison of salvia growth in seaweeds compost and biosolids compost. Compost Sci. Utilization, $8: 24-28$.

Laurie, A., D.C. Kiplinger and K.S. Nelson. 1969. Commercial Flower Forcing 6th edition. New York: McGraw Hill Book Co. Inc. 514 p.

Lentz, D., E . Sojka, W. Robbins, C. Kinca and T. Westermann. 2001. Polyacrylamid surface irrigation to increase nutrient use efficiency and protect water quality. Communi. Soil Sci. and Plant Analysis.

32(7\&8):1203-1220.

Levy, G.J. and W.P Miller. 1999. Polyacrylamide adsorption and aggregate stability. Soil Tillage Res.51: 121-128.

Lu, J.H., L. Wu and J. Letey. 2002. Effect of soil and water properties on anionic polyacrylamides sorption. Soil Sci. Soc. Am. J. 66:578-584.

Mann, K.K., A.W. Schumann, T.A. Obreza, M. Teplitski, W.G. Harris and J.B. Sartain. 2011b. "Spatial Variability of Soil Chemical and Biological Properties in Florida Citrus Production." Soil Science Society of America Journal 75. doi:10.2136/SSSAJ2010.0358.

MINITAB Inc. 2003. Minitab Statistical Software for Windows. Release 14.

Moran, R. and D. Porath. 1980. Chlorophyll determination in intact tissues using NN- dimethyl Form amid. Plant physiol., $65: 468-479$.
Mostafa, M. M. and F.A. Askar. 1997. Effect of soil conditioners on growth of Dianthus barbatus and Senecio cruents Plant J. Agric. Sci. Mansoura Univ.22(44):11551167.

MSTAT. 1988. MSTAT microcomputer statistical program. Michigan State University, East Lansing, MI.

Nader, A., M. ElShanhorey, M. A. Kattab and M. M. Mostafa. 2010. Effect ofirrigation and polyacrylamide on the production of tuberose plants in soil. Alex.J. Agric. Res.55 (3):33-42.

Neyshabouri, M.R., N., Sadegian, A.A. Jafarzadeh and M. Tourchi. 2006. Effects of polyacrylamide, pumice, and straw on infiltration and hydraulic Conductivity under sprinkler and flooded conditions. J. Agric. Sci. 16(4):

39-51. (in Persion) Page, A. L. (Ed.), 1982. Methods of Soil Analysis. Part 2. Chemical and Microbiological Methods. Agroni. No. 9. Am. Soc. Agronomy, Madison,WI.

Paz, U. 1973. Studies in growing roses in hot houses in Israel. State of Israel Ext.Service, Div. of Floriculture.

Regiane, C .M .S , C.B. Rmann and E. de Oliveira . 2005. Effect of polymers associated with $\mathrm{N}$ and $\mathrm{K}$. Biol . Technol. 48(3):1678-4324.

Sadegian, N., M.R. Neyshabouri, A.A. Jafarzadeh and M. Tourchi. 2006. Effects of three soil conditioners on the physical properties of soil surface layer.Iran. J. Agric. Sci. 37: 341- 351. (in Persion)

Santos, F. and R. P. Serralheiro 2000. Improving infiltration of irrigated Mediterranean soils with polyacrylamide. J. Agric. Eng. Res. 76:83-90.

Sarhad, J. and M. Sharif. 2014 .The effect of deficit irrigation on season growth, yield and yield components in drought condition on base of sustainable agriculture. Int. J. Farm \& Alli Sci., 3: 1061-1064.

Sepaskhah, A. R. and A. R. Basrafshan-Jahromi .2006. "Controlling runoff and erosion in sloping land with polyacrylamide under a rainfall simulator". Biosystems Engineering,.vol. 93, No. 4, pp: 469-474

Seyed, D., S. A. Golchin, and S.Ahmadi. 2010. The Effects of Different Levels of a Super Absorbent Polymer and Soil Salinity on Water Holding Capacity with Three Textures of Sandy, Loamy and Clay. J.Water Soil, (Iran). 24(2): 306-316.

Shakoor, I.A, M. Arshad, A.Tariq and I. Ahmad. 2012. Evaluating the role of bentonite amendment in controlling infiltration and improve root zone water distribution in coarse soil. Pak.J.Agri.Sci.49: 375-380.

Shanks, J. and F. Gouin. 1985. Using compost in the root medium for roses. Biocycle, 25:29-31.

Smith, R. 1993. Sewage sludge refuse composts as peat alternatives for conditioning Impoverished soil: effect on the growth response and mineral status of Petuniagradiflora. Soil Fert. Abst 56:6537.

Sndecor, G.W. and W.G. Cochran. 1974. Statistical methods. Sixth Edition Iowa State Unit. Press, Ames, Iowa, U.S.A. 
Trenkel, M. E. 1997. Controlled-release and stabilized fertilizers in agriculture. International Fertilizer Industry. Published by the International Fertilizer Industry Association Paris, December 1997.

Wafaa, M. T., E. M. Aly and T.A. Eid. 2016. Effect of irrigation regime and natural soil conditioner on crop productivity in sandy soil. Egypt. J. Soil. Sci. 55: (1-2).
Wallace, A. and G. Wallace. 1986. Additive and synergistic effect on plant growth From polymer and organic matter applied to soil simultaneously. Soil Sci., 111: 336-342.

Wallace, A. and G.Wallace. 1990. Interactions between polymer soil conditioners and organic in the improvement of physical properties of soil .J. P. Nutrit, 13 (3-4):437450.

Westerman,R.L. 1990. Soil Testing and Plant Analysis ( $3^{\text {rd }}$ ed) SSSA. Inc. Madison Wiscons in, U.S.A. 


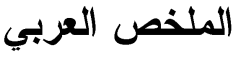

\section{تاثير محنات التربة وكمية مياه الرى على النمو والازهار لنبات الورد النامى فى ارض رملية}

سهير جمعه السيد، سحر محمد اسماعيل

(7, 19-0,VY) من محسن التزبة، وكذلك الزيادة المعنوية لمعظم التقديرات

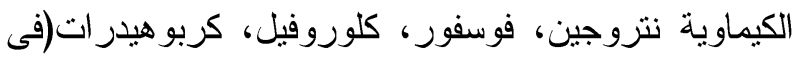

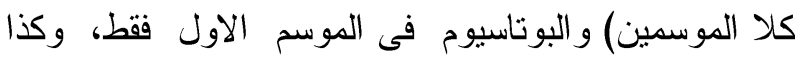
الزيادة المعنوية لصبغة الانثوسيانين. ادى اضافة البوليمر

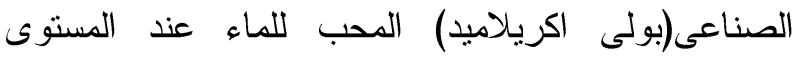
(r, ••على اساس الوزن) الى زيادة معنوية فى طول النبات، حجم الجذور ووزنها الجاف وكذلك التبكيرفى موعد الازهار و عدد الازهار/النبات وقطر الازهار ووزنها الجاف و المحتوى من الفوسفور والكلورفيل والكربوهيدرات الكلية زيادة معنوية نتيجة استخدام محسن التربة الصناعى عند

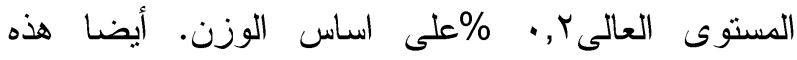
الدراسة أظهرت تأثيرات البوليمر على الحركة الرأسية لعلاقات التربة و المياه و المغذيات فى الأرض. زاد ادل معدل التويل الهيدروليكى بزيادة تركيز البوليمر وايضا لوحظ نقص فى فقد العناصر المتاحة وخاصة النتيروجين فى بـ صورة النشادر و الفوسفور فى صورة فوسفات والفوسفور الكلى مع التركيز الأعلى من البوليمر ـ ومن ناحية أخرى لم تظهر تزكيزات البوليمر تأثير على النيترات. هذه النئ النتائج تشير الى أن تطبيق البوليمر يمكن ان تكون طريقة عملية لتوفير المياه وفقد العناصر وتحسين إتاحيتها للنبات كذلك فلك يعتبر البوليمر أداة أخرى يمكن أن تستخدم لإدارة مواردنا الأرضية و المائية. يمكن التوصية بزر اعة نبات الورد فى لونى

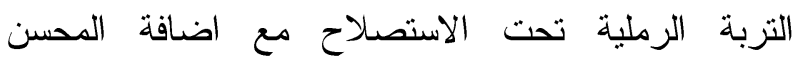

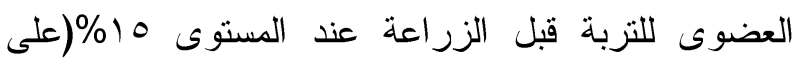

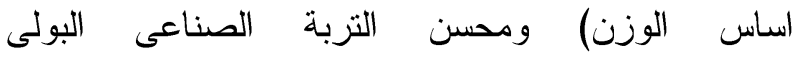
اكريلاميد , • \%(على اسانس الوزن) مع استخدام ماء الرى بمعدل •مكل/النبات/ امر ات اسبوعيا.
اجرى هذا البحث ل لمدة موسمين متتاليين

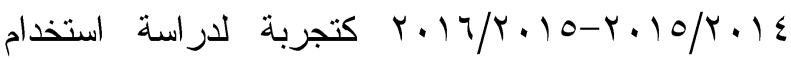
نوعين من محسنات التربة العضوى بمستويين(0، 10 \% على اساس الحجم) و الصناعى (البوليمر) البولى اكريلاميد بمستويين (ץ, • , (, ••\% على اساس الحجم) ومعدلين لماء

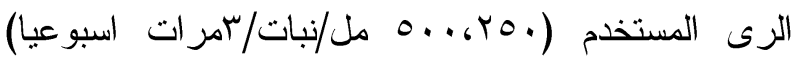
على النمو والازهار واستهلاك الماء و التركيب الكيماوى لنبات الورد النامى فى تربة رملية تحت الاستصلاح. وفيما يلى ملخصا لاهم النتائج: ادى استخدام ماء الرى بالمعدلين المذكورين الى زيادة غير معنوية فى معظم صفات النمو لهو الخضرى المدروسة وكذللك بالنسبة لصفات النمو الزهرى ماعدا صفة (موعد الازهار) حيث حدث ازهار مبكرا بصورة معنوية فى الموسم الثانى فقط. وقد زاد محتوى ب(\%) بالاوراق زيادة معنوية فى كلا الموسمين بينما البوتاسيوم و الكلوروفيل و الكربو هيدرات كانت الزيادة المعنوية فى موسم واحد فقط ولم يزد محتوى الانثوسيانين معنويا فى الموسم الواحد الذى تم تقديرها. بوجه عام ظهرت اعلى القيم الناتجة لكل صفة مدروسة نتيجة استخدام المعدل الاقل من المياه وهو .0كل/نبات / امر ات اسبو عيا. ادى اضافة محسن التزبة العضوى (مخلفات المدن) قبل الزراعة عند المستوى الاعلى (0) (10 على اساس الوزن) الى زيادة معنوية فى معظم الصفات الخضرية فى كلا الموسمين وكذللك صفات النمو الزهرى فى الموسمين ماعدا حالات قليلة.بصفة عامة الازهار المبكر(0,9؛ يوم) فى الموسم الاول فقط، القدرة الحفظية للازهار المقطوفة

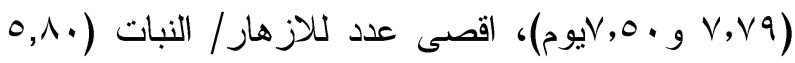

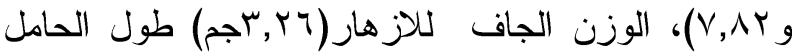

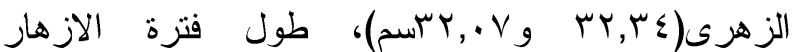

